\title{
Problematika dan Tantangan Pembelajaran Pendidikan Agama Islam di Tengah Pandemi Covid-19
}

\author{
Herman Suherman
}

\begin{abstract}
At this time all countries in the world are being hit by a major disaster caused by the Covid- 19 virus. Covid-19 virus is apparently having an impact in the world of education is no exception to the learning of Islamic religious education. In an emergency such as this Islamic religious education learning still has a very important role for students when facing the Covid-19 pandemic. Because in essence the aim of learning Islamic religious education is to increase the faith, understanding, appreciation and practice of students about Islam so that they become Muslim people who believe and have the piety of Allah SWT and have good character in their private lives, in society, nation and state. The purpose of this study is to identify the problematics of Islamic religious education learning in teaching and learning activities online (in networks) during the Covid-19 pandemic. This research uses the field research method (Field Research) and uses a descriptive qualitative approach. The data collection techniques used in this study were interview and observation. While the data analysis in this study uses qualitative data that is presented without calculation of numbers. The respondents of this study were one of the homeroom teachers and class.
\end{abstract}

Keywords: Learning problems, Islamic education, Covid-19

\section{Pendahuluan}

Pada awal tahun 2020, seluruh dunia dikejutkan dengan wabah Corona Virus Disease atau lebih dikenal dengan istilah (Covid-19) yang dikemudian hari menginfeksi hampir seluruh negara di dunia. Diduga Corona Virus Disease atau Covid-19 pertama kali muncul di Wuhan, Provinsi Hubei pada akhir tahun 2019. Bencana non alam ini atau bencana virus ini bukan pertama kalinya dihadapi negara-negara di dunia.

Penambahan dalam jumlah besar jumlah kasus COVID-19 berlangsung cukup tinggi dan sangat cepat dan menyebar ke luar wilayah Wuhan dan ke berbagai negara lain. Dalam kurun waktu sekitar 6 bulan, sudah menjangkiti 216 negara di dunia dengan virus ini. Menurut WHO, banyaknya yang terkonfirmasi dan terpapar dengan hasil pemeriksaan positif pada tanggal 25 Juni telah mencapai 9.296.202, dengan kisaran angka kematian mencapai 479.433 orang (https://Covid19.who.int/) 
Selanjutnya Presiden Republik Indonesia Joko Widodo mengumumkan mengenai kasus pertama Coronavirus Disease 2019 (Covid-19) pada akhir bulan Pebruari atau awal bulan Maret 2020 yang lalu, Indonesia kemudian dihadapkan pada masa virus yang terus menjangkit sehingga disebut pandemi. Akibat dari pandemi ini hampir seluruh sektor kehidupan mengalami lumpuh, tidak terkecuali di bidang pendidikan. Kementerian Pendidikan dan Kebudayaan (Kemendikbud) kemudian bersikap dengan kondisi tersebut, yang diantara kebijakan menyikapi kondisi tersebut dengan membuat sejumlah kebijakan.

Penggunaan teknologi yang pada mulanya lebih banyak sebagai pendukung dalam bekerja atau sekunder atau malah rekreasi, berubah menjadi fasilitas yang utama dalam bekerja. Termasuk dalam pendidikan pun menggunakan pembelajaran jarak jauh. Pada kenyataannya banyak kesulitan yang dialami, baik oleh para guru, para siswa dan orang tua dalam melaksanakan pembelajaran jarak jauh di saat terjadi darurat Covid 19. Guru yang belum terbiasa dengan menggunakan perangkat gaget atau smartphone akan kesulitan dalam melaksanakan pembelajaran di masa Covid 19 khususnya dalam mempasilitasi pembelajaran kepada peserta didik secara daring. Belum meratanya jaringan signal keseluruh pelosok, menambah kesulitan yang dihadapi oleh para siswa dalam mengakses pembelajaran. Selanjutnya kondisi orang tua yang belum seluruhnya bisa memberikan perlatan handphone android kepada siswanya menambah sederet permasalahan dalam pembelajaran di masa pandemi Covid 19 ini.

Pembelajaran untuk mata pelajaran Pendidikan Agama Islam (PAI) dibutuhkan proses pembelajaran yang tidak hanya teori tetapi juga praktik. Seperti bagaimana praktik sholat, praktik memandikan jenazah, praktik membaca al-quran dan lain-lain. Hal ini sulit dilakukan tanpa adanya pertemuan secara fisik dengan para siswa. Pelajaran praktik ini tidak cukup dengan penayangan vidio, atau penayangan materi secara daring, karena dibutuhkan tuntunan dari guru agar ketika ada kesalahan siswa pada saat praktik dapat langsung diluruskan.

Pembelajaran online yang dilakukan dengan melakukan interaksi positif antara pembelajar (peserta didik) dengan berbagai sumber belajarnya (database, pakar/instruktur, perpustakaan) yang secara lahiriah berjauhan aau terpisah namun nyata dapat saling berkomunikasi, melakukan interaksi atau berkolaborasi dalam kegiatan pembelajaran (secara langsung atau tidak langsung yang lebih dikenal dengan istilah synchronous atau asynchronous.

Salah satu aplikasi yang gratis dan familiar yang bisa diterapkan untuk kegiatan pembelajaran jarak jauh adalah aplikasi Google Classroom. Guru sebagai pendidik dan siswa atau peserta didik dalam menggunakan aplikasi GCR ini dimungkinkan untuk melakukan kontak melalui forum diskusi atau chat atau ngobrol (stream) terkait dengan permasalahan materi pembelajaran dan jalannya pembelajaran secara interaktif antara guru dan siswa. 


\section{METODE}

Penulisan artikel ini menggunakan metode studi perbadingan literature dan analisis konten. Kegiatan membandingkan literatur satu dengan literatur lain dilakukan untuk mengungkap berbagai teori dan informasi yang relevan dengan topik yang dikaji. Studi dengan membandingkan literatur satu dengan literatur lain dilakukan dengan menelusuri literatur primer secara daring, yaitu jurnal, laporan penelitian, laporan kegiatan, buku, majalah, media berita, dan sumber literatur lainnya, yang memiliki kriteria valid dan bereputasi baik. Jurnal, prosiding, dan buku yang digunakan diprioritaskan berasal dari database Scopus (https://www.scopus.com/home.uri), dan ERIC Institute of Education (https://eric.ed.gov/). Literatur juga diperoleh dari Google Cendekia (https://scholar.google.co.id/), khusus literatur berbahasa Indonesia, literatur yang diterbitkan di Indonesia, dan literatur yang ditulis oleh author dari Indonesia. Literatur lainnya ditelusur menggunakan mesin pencari Google. Kata kunci yang digunakan untuk mencari berbabai tulisan menggunakan bahasa Inggris, yaitu COVID-19, COVID and education, pandemic and education, outbreak and learning, teaching in pandemic, outbreak and education, dan learning technology and pandemic era. Kata kunci yang digunakan untuk menelusur literature menggunakan bahasa Indonesia, yaitu COVID-19 di Indonesia, Pendidikan dan COVID, pendidikan masa bencana, pendidikan masa wabah, guru dan COVID, tantangan pendidikan masa depan, dan pembelajaran daring dan COVID.

Tahapan dalam kegiatan membandingkan literatur satu dengan literatur lain yang digunakan dalam menyusun artikel ini mengacu pada Zed (2008) dan Khatibah (2011). Ada empat langkah yang harus dilakukan, yaitu (1) mempersiapkan peralatan: dalam bentuk pensil/ballpoint, buku catatan, dan komputer/laptop yang terhubung dengan jaringan internal; (2) menyusun bibliografi; (3) mengatur waktu dan fokus pada kegiatan; dan (4) membaca secara cermat, mencatat, dan menulis hasil.

Analisis data menggunakan paradigma analisis konten. Penyajian data menggunakan metode presentasi informal. Dalam penyajian data, penulis mengikutsertakan kutipan dari berbagai referensi yang digunakan, dalam bentuk hasil analisis, menyebutkan sumber dan diilustrasikan berdasarkan ringkasan atau esensi informasi (yang bisa saja akan berbentuk parafrase berbeda namun tetap sama makna) untuk setiap topik yang dianalisis. Hal tersebut dilakukan dengan konteks pemikiran kritis dan analisis informasi secara mendalam. 


\section{HASIL DAN PEMBAHASAN}

\section{Pembelajaran di masa pandemi COVID-19}

Dunia sedang berjuang melawan COVID-19, lembaga pendidikan harus cepat melakukan antisipasi (Snelling \& Fingal, 2020). Sebagaimana yang dilakukan pada pandemi influenza, praktek yang paling sering diterapkan oleh sekolah adalah membatalkan atau menunda kegiatan pembelajaran di sekolah, membatalkan kelas atau kegiatan dengan tingkat pencampuran/kontak yang tinggi yang terjadi dalam jam belajar, dan mengurangi interaksi fisik selama menggunakan alat transportasi (Uscher-Pines et al., 2018).

Lebih lanjut diuraikan bahwa tingkat kelanjutan dan kemungkinan intervensi pendidikan meliputi: (1) Paparan terhadap konten: Siswa akan dapat melihat konten yang luas terkait dengan materi yang diajarkan, seperti literasi dan berhitung. Pengembangan keterampilan yang terlalu terfokus cenderung tidak diharapkan karena akan membuat siswa jenuh. Bahan yang digunakan mungkin termasuk buku teks, buku kerja, lembar kerja, email, televisi (mis., DVD, kabel, streaming), dan konten Internet (misalnya website dan game), namun itu bergantung pada tingkat kelas dan kemampuan sekolah. (2) Konten tambahan: Siswa akan dapat melihat dan berpartisipasi dalam kegiatan yang berhubungan langsung dengan keterampilan, tetapi sebaiknya tidak perlu dilakukan penilaian atau evaluasi pekerjaan, ini lebih lebih pengayaan saja. Diharapkan ada kemajuan yang diperoleh siswa meskipun secara terbatas. Selain materi yang tercantum di atas, materi pelajaran yang lebih spesifik dapat disediakan melalui konten yang dapat diunduh (misalnya menggunakan laptop dan smartphone) dan komunikasi melalui telepon (misalnya video conference dan komunikasi video call satu-satu). (3) Kelanjutan terpisah: Siswa juga dapat mengakses konten dan materi pelajaran yang lain. Jika dukungan instruksional (termasuk penilaian dan evaluasi kerja) diberikan melalui media lain, pembelajaran berkelanjutan mungkin perlu dilakukan. Terkait dengan hal ini, kemajuan siswa mungkin dapat diukur. Bahan dan metode pengajaran yang digunakan mungkin mencakup semua yang tercantum di atas serta pembelajaran daring yang bersifat sinkron (misalnya chatting, streaming, video, pesan singkat, dan/atau web conference). (4) Kelanjutan penuh: Siswa dapat mengakses konten dan materi pelajaran. Dukungan instruksional diberikan, termasuk penilaian dan evaluasi pekerjaan. Kemajuan siswa yang terukur diharapkan. Bahan dan metode pengajaran yang digunakan mungkin mencakup semua yang tercantum di atas serta pembelajaran daring yang asinkron dengan kemampuan untuk komunikasi dan penilaian jarak jauh (misalnya, e-mail, learning management systems, tracking, dan pengelolaan kelas atau proyek). (5) Penilaian: jadwal ujian di seluruh negara bagian akan terbuka sesuai jadwal; Dinas pendidikan bekerja dengan vendor jika waktu ujian perlu diperpanjang. Sekolah wajib mengikuti ujian yang dijadwalkan sesuai rencana. Jika ada penutupan, sekolah mungkin perlu menunda ujian dan berkumpul kembali pada saat adanya pembukaan. Jika ada penutupan, waktu ujian akan 
diperpanjang. Dinas Pendidikan bekerjasama dengan Dewan Pendidikan Negara Bagian untuk menyelesaikan setiap masalah yang muncul ketika ujian dan dampak yang mungkin terjadi terkait akuntabilitas.

Melania (2020) telah melakukan survei terhadap siswa yang melakukan kegiatan pembelajaran daring. Hasil menunjukkan bahwa sebagian siswa menerima pembelajaran daring dengan alasan bahwa pembelajaran daring lebih santai, menyenangkan, fleksibel, efisien, singkat, praktis, cepat, tepat, aman, mudah, hemat waktu, dan hemat tenaga. Cara itu juga bisa dilakukan secara jarak jauh tanpa berkumpul di tempat yang sama. Selain itu, manfaat lain pembelajaran daring adalah orang tua bisa mengawasi anak-anaknya belajar, membuat siswa atau guru menjadi melek teknologi, mempercepat era 5.0, serta meningkatkan kemampuan di bidang IPTEK. Siswa juga mengatakan bahwa mereka menjadi lebih kreatif dalam menyelesaikan tugas dan dapat mengkondisikan diri senyaman mungkin untuk belajar tanpa aturan yang formal.

\section{Problematika Pembelajaran PAI}

Dalam kegiatan pembelajaran pendidikan agama Islam tentu ada tujuan yang ingin dicapai oleh seorang pendidik dan peserta didik. Untuk mencapai tujuan pendidikan agama Islam diperlukan pelaksanaan pembelajaran yang baik, dalam pelaksanaan pembelajaran pendidikan agama Islam terdapat faktor yang dapat mempengaruhinya baik dari faktor pendidik, peserta didik, faktor sarana dan prasarana, dan faktor lingkungan.

Dalam dunia pendidikan tentu kita tidak jauh dari suatu problem atau masalah, tanpa terkecuali untuk belajar pendidikan agama Islam. Setiap permasalahan yang terjadi, tentu ada penyelesaiannya, jika kita dapat memperoleh solusinya, maka dapat mempermudah proses belajar serta bisa memberikan hasil yang lebih optimal. Ada beberapa problem atau masalah yang didapati dalam kegiatan pembelajaran antara lain keterbatasan sumber belajar, alokasi waktu, dan keterbatasan dana yang tersedia. Dalam bahasa inggris "problematic" artinya adalah masalah atau persoalan, dan dalam Kamus Besar Bahasa Indonesia, problematika artinya suatu masalah yang mengakibatkan persoalan dan masih belum bisa dipecahkan.

Dalam pembelajaran pendidikan agama Islam tentu ada tujuan yang hendak dicapai. Tujuan dari pembelaran pendidikan agama Islam adalah ingin meningkatkan keimanan, pemahaman, penghayatan dan pengamalan peserta didik tentang agama Islam sehingga menjadi manusia muslim yang beriman dan bertaqwa Allah SWT serta berakhlak mulia dalam kehidupan pribadi, bermasyarakat, berbangsa dan bernegara. Kemudian secara umum pembelajaran pendidikan agama Islam bertujuan untuk membentuk pribadi manusia menjadi pribadi yang mencerminkan ajaran- ajaran Islam dan bertakwa kepada Allah, atau "hakikat tujuan pembelajaran pendidikan Islam adalah terbentuknya insan kamil". 
Menurut Datik Nurmuslimah dan Istanto tujuan pembelajaran adalah mewujudkan generasi bangsa yang memiliki semangat juang tinggi untuk mendapatkan ilmu sehingga mampu menjadi dirinya menjadi pribadi yang lebih berkualitas. Pribadi yang berkualitas yaitu pribadi yang menjadikan pendidikan sebagai sumber harapan besar untuk mecapai tujuan yang diharpakannya, untuk mencapai tujuan tersebut, maka pendidikan juga harus berkualitas. Pendidikan berkualitas bisa didapatkan dari sekolah yang berkualitas unggul.

Menurut H.M. Arifin yang dikutip oleh Miss Bismee Chamaeng mengemukakan bahwa tujuan pembelajaran pendidikan agama Islam adalah "membina dan mendasari kehidupan anak dengan nilai-nilai syariat Islam secara benar sesuai dengan pengetahuan agama" Sedangkan Iman al-Ghazali berpendapat bahwa tujuan pendidikan Islam yang paling utama adalah "beribadah dan bertaqarrub kepada Allah kesempurnaan insan yang tujuannya kebahagiaan dunia dan akhirat".

Berikut ini macam-macam problematika pembelajaran pendidikan agama Islam yang di hadapi oleh pendidik dan peserta didik pada masa pandemi Covid-19:

1. Faktor Pendidik

Dalam kegiatan pembelajaran pada masa pandemi Covid -19 ini, tentu tidak lepas dari problem atau masalah yang dihadapi oleh guru saat mengajar. Sehingga seorang guru harus pandai dalam mencari solusi dalam suatu persoalan atau problematika pembelajaran. Hal ini dikarenakan jika problem tersebut tidak segera di atasi maka akan menimbulkan permasalahan atau hambatan dalam proses pencapaian tujuan pembelajaran. Berikut ini problematika yang dihadapi oleh seorang guru pada masa pandemi Covid-19: a. Keterbatasan sarana prasarana

Dari hasil penelitian problem yang dirasakan oleh seorang guru adalah kurang efektifnya kegiatan belajar karena dilaksanakan dengan sarana prasarana yang kurang lengkap sehingga anak didik tidak dapat bertatap muka secara langsung dengan guru. Kurangnya fasilitas yang memadai pada saat pelaksanaan pembelajaran dirumah akan memunculkan kekurang pahaman tentang materi yang disampaikan guru kepada peserta didiknya. Seharunya untuk mempermudah pembelajaran secara (daring) perlu dipersiapkan terlebih dahulu sarana prasaranya seperti laptop, komputer atau hand phone yang dapat mempermudah guru dalam melakukan kegiatan pembelajaran. Karena jika dalam kegiatan belajar mengalami keterbatasan fasilitas maka akan menghambat proses pembelajaran dan mempengaruhi pencapaian hasil belajar.

b. Penguasaan teknologi yang masih rendah

Dalam pelaksanakan kegiatan pembelajaran secara daring (online) tidak semua guru trampil dalam menggunakan teknologi internet dan media sosial. Ada sebagian guru yang masih memerlukan bimbingan dan pelatihan 
terlebih dahulu untuk memakai alat atau bahan yang digunakan saat kegiatan belajar mengajar secara daring. Sehingga karena adanya wabah Covid-19 ini, guru harus mau belajar dan bersedia memberikan pelajaran secara online.

c. Kurangnya keefektifan belajar mengajar

Berdasarkan hasil penelitian berupa wawancara kepada bapak Zainul Arifin didapatkan fakta bahawa tingkat hasil belajar siswa menurun, hal ini dikarenakan kurangnya keefektifan dalam pembelajaran secara daring yang tidak memungkan siswa untuk melakukan pembelajaran secara ferbal atau secara langsung, sehingga siswa tidak bisa berinteraksi dan berduskusi secara langsung dengan teman sekelasnya maupun dengan guru PAI.

2. Faktor Peserta Didik

Dalam proses kegiatan pembelajaran pendidikan agama Islam pada masa pandemi Covid-19 tentu ada beberapa problem atau masalah yang dialami oleh peserta didik. Problem atau masalah tersebut dapat dilihat dari beberapa sudut pandang, misalnya dilihat dari segi proses belajarnya atau situasi belajarnya. problem tersebut antara lain:

a. Kurang Melakukan Budaya Literasi

Dari hasil wawancara kepada peserta didik, ternyata ada salah satu peserta didik yang lupa akan tanggungjawabnya sebagai pribadi muslim. Peserta didik mulai tidak tepat waktu dalam melaksanakan sholat wajib, tidak melaksanakan sholat dhuha, hafalan dan mulai tidak membaca Al-Qur'an seperti yang telah diterapkan disekolahan sebelum pembelajaran dimulai. Seharusnya dalam kondisi seperti ini peserta didik tetap menjalankan tugasnya dan tetap menaati aturan meski tidak dalam pengawasan guru. Namun kenyataannya peserta didik hanya mau mengerjakan tugas dan menaati aturan jika berada dalam pengawasan yang ketat dari guru. Sehingga ketika peserta didik melakukan pembelajaran secara daring atau dirumah masing-masing, peserta didik merasa lebih bebas dan leluasa untuk melakukan semua hal dengan sesuka hatinya. Ajaran-ajaran agama yang telah didapatkan disekolahan tidak diterapkan kembali ketika dirumah.

b. Tingkat pemahaman agama yang berbeda-beda

Dari hasil wawancara kepada peserta didik ternyata ada beberapa tingkat pengetahuan peserta didik yang berbeda. Salah satu dari peserta didik yang diwawancarai ada 2 kategori peserta didik yang sudah memiliki dasar pengetahuan agama melalui pendidikan orang tuanya dirumah, dan ada juga peserta didik yang sudah mendapatkan dasar pengetahuan dari jenjang sekolah yang telah dilaluinya. Peserta didik yang telah memiliki ilmu pengetahuan agama dengan peserta didik yang belum memiliki ilmu pengetahuan agama, akan menjadi masalah dalam pembelajaran pendidikan agama Islam. Dengan demikian peserta didik yang berada dalam keluarga beragama dan dalam pendidikan berikutnya mereka memperoleh pendidikan agama yang baik, maka mereka akan menjadi orang yang taat beragama, dan begitu sebaliknya jika dasar agama yang dimilikinya itu tidak dijaga dan dibina 
dengan baik, maka peserta didik akan menjadi orang yang tidak beragama, dan ilmu pendidikan agamanya juga akan hilang.

c. Kemauan siswa yang rendah untuk belajar

Beberapa pengaruh yang dialami oleh peserta didik pada saat kegiatan pembelajaran pada masa pandemi Covid-19 ini adalah peserta didik harus belajar secara jarak jauh dengan fasilitas yang kurang memadai. Dengan kurangnya fasilitas dalam pembelajaran akan membuat peserta didik menjadi kurang minat dalam belajar agama. Peserta didik yang tidak bersungguhsungguh dalam mempelajari agama pasti tujuannya hanya ingin mencari nilai saja, bukan untuk membekali dirinya dengan pengetahuan agama sebagai sarana untuk melaksanakan ibadah kepada Allah SWT. Sedangkan peserta didik yang bersungguh-sungguh dalam belajar agama pasti akan lebih memperhatikan, mendalami dan menghayati setiap ajaran agama yang didapatkannya, dan akan mengamalkan ajaran tersebut dalam kehidupan sehari-hari.

d. Keberagaman pengetahuan siswa yang berbeda-beda

Dalam kegiatan pembelajaran tidak semua peserta didik mempunyai kecerdasan yang sama, Izza Yusfiana menyatakan bahwai ia mengalami kesulitan dalam kegiatan pembelajaran mata pelajaran pendidikan agama Islam, karena guru yang terlalu banyak memberikan tugas, sehingga Izza Yusfiana tidak bisa mengerjakan semua tugasnya dengan maksimal. Namun bagi peserta didik yang mempunyai tingkat kecerdasan yang lebih tinggi akan lebih mudah menerima pelajaran agama dibandingkan peserta didik yang memiliki tingkat kecerdasan lebih rendah. Masalah ini juga akan menyebabkan faktor munculnya problem pembelajaran pendidikan agama Islam yang diberikan oleh pendidik. Dengan demikian seorang pendidik harus tau tingkat kecerdasan setiap peserta didiknya, jangan sampai guru memberikan tugas yang tidak sesuai dengan kemampuannya, sehingga peserta didik tidak mampu untuk menyelesaikannya. Sehingga pada masa pandemi saat ini guru dan siswa harus mau beradaptasi dan terus belajar dalam berbagi platform pembelajaran secara online, supaya peserta didik mampu mencapai hasil belajar secara maksimal sesuai dengan yang di inginkannya.

e. Lingkungan Keluarga

Keluarga adalah tempat pendidikan nomer satu untuk seorang anak, dilingkungan keluarga inilah anak akan mendapatkan banyak pendidikan agama dan bimbingan tentang keagamaan, karena sebagian besar aktivitas anak berada dilingkungan keluarga. Dengan demikian, jika keluarga peserta didik tersebut tingkat keagamaannya baik dan selalu memberikan support kepada anaknya maka secara otomatis perkembangan pendidikan agama anak akan baik pula. Sebaliknya jika lingkungan keluarga kurang memberikan support kepada anaknya maka perkembangan anak didik akan berbeda jauh dengan hal di atas. Oleh karena itu, dengan adanya Covid-19 ini pemerintah 
mengeluarkan kebijakan WFH (work from home), yang mana kebijakan tersebut menyarankan kepada masyarakat untuk melakukan semua pekerkjaannya dari rumah. Sehingga hal tersebut membuat orang tua tidak bisa memantau anaknya dengan baik.

f. Lingkungan Masyarakat

Lingkungan masyarakat sangat berpengaruh besar terhadap tumbuh kembang peserta didik, karena perkembangan jiwa peserta didik sangat dipengaruhi oleh keadaan lingkungannya. Jika peserta didik bersosialisasi dengan masyarakat yang agamis maka ia akan selalu berusaha menyeimbangkan dirinya dengan kebiasaan-kebiasaan baik dilingkungan sekitarnya tersebut, dan begitu sebaliknya jika peserta didik bersosialisasi dengan masyarakat yang abangan, otomatis peserta didik juga akan mengikuti kebiasaan- kebiasaan buruk dilingkungan sekitanya tersebut. Dari hasil wawancara yang dilakukan oleh peneliti kepada Ayu Citra Lestari, ia menjelaskan bahwa ia bertempat tinggal dilingkungan masyarakat yang kurang mendukung, sehingga terkadang sikap dan tingkahlakunya terbawa dengan kebiasaan-kebiasaan buruk dilingkungan sekitarnya.

g. Lingkungan Bermain

Lingkungan bermain dalam sehari-hari sering disebut sebagai lingkungan pergaulan, jika seorang anak berada dilingkungan yang temantemannya baik dan rajin, maka kemungkinan besar anak itu juga akan terpengaruh kepada hal yang baik dan akan mengikuti tingkah laku seperti teman yang lainnya. Namun, jika anak bergaul dengan teman-teman yang tidak baik, maka akan berpengaruh negative juga terhadap perkembangan anak tersebut. Karena pengaruh teman itu sangat berpengaruh besar terhadap anak dan sulit sekali untuk dihindari, maka perlu sekali ditanamkan pembiasaan keagamaan, kedisiplinan dan tanggung jawab kepada dirinya sendiri. Dari hasil wawancara yang dilakukan peneliti kepada Rohim Andi Prasetyo, ia menjelaskan bahwa ia sering lupa waktu ketika bermain dengan temantemannya, karena teman-temannya yang selalu mengajaknya bermain game Mobile Legends, sehingga ia melupakan tugas- tugasnya yang diberikan oleh gurunya.

Problematika, Tantangan pembelajaran PAI pada Masa Pandemi Covid-19 dan solusi mengatasinya

Pembelajaran dengan menggunakan teknologi baru memang telah berjalan selama beberapa dekade. Akan tetapi, dapat dikatakan bahwa dampak transformational sebagaimana yang diharapkan belum tercapai (Trucano, 2014). Sehubungan dengan itu, peralihan ke pembelajaran daring tentu saja bukanlah solusi yang benar-benar sempurna. Di Amerika Serikat saja, banyak profesor yang tidak pernah mengajar secara daring, sementara dukungan teknis sering kurang memenuhi. Beberapa kritik muncul tentang apakah perlu perubahan seperti itu tanpa keterlibatan insititusi yang memadai. Lainnya 
mempertanyakan apakah model yang hanya menggunakan daring akan menghukum siswa yang mungkin tidak memiliki akses digital atau internet (The Chronicle of Higher Education, 2020).

Pelaksanaan pembelajaran daring bukan tanpa masalah. Di beberapa negara, dilaporkan bahwa di antara mereka yang mengadopsi pembelajaran daring, rata-rata manfaat sebenarnya jauh lebih kecil daripada yang diharapkan. Masalah jaringan, kurangnya pelatihan, dan kurangnya kesadaran dinyatakan sebagai tantangan utama yang dihadapi oleh pendidik. Kurangnya kesadaran dinyatakan sebagai alasan paling penting oleh mereka yang tidak mengadopsi pembelajaran daring diikuti oleh kurangnya minat dan keraguan tentang kegunaan pembelajaran daring. Kurang kehadiran, kurangnya sentuhan pribadi, dan kurangnya interaksi karena masalah konektivitas ditemukan menjadi kelemahan signifikan dari pembelajaran daring (Arora \& Srinivasan, 2020). Menurut M. Wahyudi (2020) fakta di lapangan, kewajiban belajar di rumah menjadi kendala serius khususnya peserta didik dari kalangan yang kurang beruntung secara ekonomi. Mereka sering mengeluhkan habisnya paket kuota internet. Selain itu, teknologi dianggap dapat membangun sikap instan bagi para penggunanya.

Menurut Tim Kompas (2020), laporan dari sejumlah daerah di Indonesia menunjukkan bahwa penerapan pembelajaran daring belum berjalan optimal, terutama di daerah pelosok dengan teknologi dan jaringan internet terbatas. Gambar 2 menunjukkan bahwa pada tahun 2018 saja secara nasional hanya $39,90 \%$ penduduk yang mengakses internet. Kesiapan infrastruktur sekolah, kemampuan guru mengajar secara daring, serta ketersediaan sarana smartphone menjadi persoalan lain dalam penerapan pembelajaran daring di Indonesia.

Hal ini sejalan dengan hasil penelitian Purwanto et al (2020) ini yaitu terdapat beberapa kendala yang dialami oleh murid, guru dan orang tua dalam kegiatan belajar mengajar daring yaitu penguasaan teknologi masih kurang, penambahan biaya kuota internet, adanya pekerjan tambahan bagi orang tua dalam mendampingi anak belajar, komunikasi dan sosialisasi antar siswa, guru, dan orang tua menjadi berkurang dan Jam kerja yang menjadi tidak terbatas bagi guru karena harus berkomunikasi dan berkoordinasi dengan orang tua, guru lain, dan kepala sekolah. Selain itu, menurut Anugrah (2020) seiring perjalanan waktu muncul banyak permasalahan dalam implementasi pembelajaran daring. Di antara permasalahan itu adalah tugas guru yang terlalu banyak dan keluhan soal kuota dan jaringan internet yang serba terbatas. Kondisi tersebut sejalan dengan hasil riset Kementerian Pemberdayaan Perempuan dan Perlindungan Anak pada bulan Maret 2020 dengan subyek peserta didik usia 14-17 tahun (69\% perempuan dan 31\% laki-laki) berjumlah 717 dari 29 provinsi di seluruh Indonesia. Hasil menunjukkan bahwa 58\% peserta didik tidak suka menjalani program belajar dari rumah. Faktor penyebabnya adalah peserta menganggap bahwa komunikasi dengan teman 
menjadi terbatas, mereka mengalami keterbatasan teknologi: berupa fasilitas internet, gawai, dan buku elektronik. Mereka juga mengangap bahwa sekolah tidak memiliki program yang baik untuk sistem belajar di rumah. Sekolah dan guru hanya memberi tugas secara beruntun sesuai rencana pelajaran dan materi pelajaran dalam kondisi non-pandemi/kondisi biasa (Satriawan, 2020).

Komisi Perlindungan Anak Indonesia juga melaporkan bahwa mereka telah menerima sebanyak 213 pengaduan peserta didik dan orang tua di berbagai daerah terkait pembelajaran daring. Kebanyakan peserta didik melaporkan perihal tugas harian yang diberikan guru yang dianggap berat sementara waktu pengerjaan rekatif pendek. Proses pembelajaran daring terassemakin berat bagi peserta didik yang tidak memiliki kuota internet, atau bahkan mereka tidak memiliki komputer (Madrim, 2020).

Meskipun demikian, patut diduga bahwa ada satu hal yang menjadi pendukung atau pendorong positif, yaitu semakin tingginya angka pengguna smartphone-sehingga menyebabkan teknologi ini menjadi kebutuhan primermendorong kemudahan mengakses internet secara massif dan lebih luas. Menurut Mila (2018), banyaknya penduduk yang menggunakan smartphone menyebabkan teknologi ini yang paling banyak digunakan untuk mengakses internet. Pada tahun 2014 saja, akses internet di Indonesia sebesar 85\% menggunakan smartphone.

Beberapa upaya yang harus dilakukan dalam mengatasi problematika pembelajaran pendidikan agama Islam pada ma pandemi Covid-19. Upaya tersebut antara lain:

a. Saran untuk guru dalam menghadapi problematika pembelajaran pendidikan agama Islam pada masa pandemic Covid-19 :

1) Seharusnya sebelum dilakukannya program pembelajaran online perlu dipersiapkan terlebih dahulu fasilitas pendukung pembelajaran seperti hand phone, laptop, kuota, agar tidak mempengaruhi kualitas hasil belajar mengajar.

2) Upaya yang selanjutnya yaitu melakukan pelatihan terlebih dahulu terhadap peserta didik dan guru. Karena tidak semua siswa terbiasa belajar dengan menggunakan pembelajaran online dan tidak semua guru bisa melakukan pembelajaran dengan menggunakan teknologi internet atau media sosial yang lainnya.

b. Saran untuk siswa siswa dalam menghadapi problematika pembelajaran pendidikan agama Islam pada masa pandemic Covid-19 :

1) Dalam keadaan seperti ini dukungan guru dan sekolahan dengan orang tua sangat dibutuhkan oleh peserta didik. Sehingga guru dan sekolahan dengan orang tua harus menjalin hubungan komunikasi yang baik. Dengan tujuan membantu guru untuk tetap memantau peserta didik agar tetap menjalankan tugasnya meski pembelajaran tidak dilakukan disekolahan.

2) Upaya yang selanjutnya adalah melakukan sosialisasi kepada anak 
agar tidak melupakan tugas-tugas dan tanggung jawabnya sebagai anak dan sebagai pelajar. Agar anak tetap melakukan tugas-tugasnya dan tanggung jawabnya meski tidak dalam patauan guru.

3) Selanjutnya upaya yang harus dilakukan adalah, menerapan pembiasaan kedisiplinan sholat wajib tepat waktu, sholat dhuha, dan membaca Al-Qur'an seperti yang telah diajarkan disekolahan agar peserta didik tetap melakukan pembiasaan tersebut meski tidak berada dalam pantauan guru.

4) Upaya yang selanjutnya adalah, tidak membiarkan anak terlalu lama bermain dengan teman-teman yang berada dilingkungan yang kurang baik, tujuannya agar anak tersebut tidak terpengaruh oleh kebiasaan-kebiasaan buruk temannya. Sehingga dalam kondisi seperti ini jangan sampai anak merasakan bebas leluasa dan anak tersebut lupa akan tugasnya sebagai peserta didik.

\section{KESIMPULAN}

Problematika pembelajaran pendidikan agama Islam pada masa pandemi Covid-19 sangat berpengaruh tehadap guru dan siswa. Karena dalam keadaan seperti ini tanpa ada pelatihan atau persiapan terlebih dahulu guru dan siswa dipaksa untuk mau tidak mau harus bisa melakukan kegiatan belajar mengajar dengan menggunakan berbagai macam platform secara online. Selain itu pembelajaran pada masa pandemic Covid- 19 ini juga berpengaruh terhadap sikap dan tingkah laku anak ketika berada dirumah, karena siswa merasa dirinya tidak berada dalam pantauan guru sehingga mereka dapat bertingkah semaunya dan bebas melakukan semua hal tanpa mereka sadari bahwa mereka juga mempunyai tanggungjawab meski pembelajaran pendidikan agama Islam tidak dilakukan disekolahan. Siswa mulai tidak melakukan tanggungjawabnya sebgai prbadi muslim, mereka mulai enggan untuk menjalankan sholat wajib, sholat dhuha, dan membaca AlQur'an. Padahal semua itu telah diajarkan oleh guru ketika berada disekolahan, harapannya siswa tetap melakukan itu ketika berada dirumah, namun ternyata ketika siswa berada dirumah siswa enggan untuk melakukannya. Mereka menganggap bahwa belajar agama itu hanyalah sebuah ritual saja, tujuan utapanya hanya ingin mencari nilai saja, sehingga mereka tidak bersungguh-sungguh dalam belajar agama. Dengan demikian perlu sekali bimbingan orang tua dirumah untuk menerapkan pembiasaanpembiasaan yang telah diajarkan disekolahan, agar siswa tetap melakukan tanggungjawabnya meski tidak berada dalam pantauan guru. 


\section{DAFTAR PUSTAKA}

Abdullah, R. (2016). Pembelajaran dalam perspektif kreativitas guru dalam pemanfaatan media pembelajaran. Lantanida Journal, 4(1), 35-49. https://doi.org/10.22373/lj.v4i1.1866

Aderholt, R. (2020, March). Coronavirus outbreak shining an even brighter light on internet disparities in rural America. The Hill.

Anderson, J. (2020, March). Should schools close when coronavirus cases are still rare? Quartz.

Anugrah, D. (2020). Dinamika pembelajaran daring di tengah pandemi Covid-19. Berita Magelang. Arizona Department of Education. (2020). Pandemic preparedness (Issue March). Arizona Departmernt of Education.

Chamaeng, Bismee, Miss. 2017. Problematika Pembelajaran PAI (Pendidikan agama Islam ) Di Sekolah Samaerdee Wittaya Provinsi Patani Selatan Thailand, Skripsi. Semarang: Fakultas Tarbiyah dan Keguruan, Universitas Negeri Walisongo.

Firtiani, Yuni \& Pakpahan, Roida. 2020. “Analisa Pemanfaatan Teknologi Informasi Dalam Pembelajaran Jarak Jauh Di Tengah Pandemi Virus Corona Covid-19", Journal of Information System, Appied, Management, Accounting and Reseach, 4, (2), 30.

Ikhwani. 2017. Problematika Pembelajaran Pendidikan agama Islam dan Solusi yang dilakukan Sekolah dan Guru Pendidikan agama Islam Di SMA Negeri 2 Takalar, Skripsi. Makassar, Fakultas Tarbiyah dan Keguruan, Universitas Islam Negeri Makassar

Kemendikbud. (2020). Belajar dari rumah, satuan pendidikan dapat pilih platform pembelajaran jarak jauh sesuai kebutuhan (Learning from home, education units can choose distance learning platforms as needed). Kementerian Pendidikan dan Kebudayaan, Republik Indonesia.

Madrim, S. (2020, April). KPAI: Siswa keluhkan pembelajaran berat di tengah wabah corona. VOA Indonesia.

Melania, E. P. (2020, April). Pembelajaran daring, apakah efektif untuk Indonesia. Kompas.

Mila, M. (2018). Pengembangan media multi representasi berbasis Instagram sebagai alternatif pembelajaran daring. Universitas Islam Negeri Raden Intan Lampung. 
